\title{
ANALISIS PAJANAN TIMBAL UDARA DAN TIMBAL DALAM \\ DARAH DENGAN TEKANAN DARAH DAN HEMOGLOBIN (Hb) \\ PADA OPERATOR SPBU
}

\section{ANALYSIS ON AIR LEAD EXPOSURE AND LEAD CONCENTRATION IN BLOOD ASSOCIATED WITH BLOOD PRESSURE AND HEMOGLOBIN (Hb) OF ATTENDANTS OF PETROL STATION}

\author{
${ }^{1}$ Ayu Rofia Nurfadillah ${ }^{2}$ Irwan \\ ${ }^{12}$ Fakultas Olahraga dan Kesehatan, Universitas Negeri Gorontalo, \\ ${ }^{1}$ Email : ayu@ung.ac.id \\ 2Email : irwandel@yahoo.com
}

\begin{abstract}
Abstrak
Stasiun pengisian bahan bakar umum (SPBU) merupakan tempat yang sangat potensial mencemari lingkungan di sekitarnya terutama pencemaran udara timbal yang berasal dari penguapan bensin maupun akibat dari pengeluaran gas buang kendaraan bermotor. Penelitian ini bertujuan untuk mengetahui hubungan pajanan timbal $(\mathrm{Pb})$ di udara dan konsentrasi timbal $(\mathrm{Pb})$ dalam darah dengan tekanan darah dan $\mathrm{Hb}$ pada operator SPBU di Ruas Jalan Perintis Kemerdekaan. Penelitian ini merupakan jenis penelitian observasional dengan menggunakan design cross sectional. Sampel sebanyak 30 responden yang dipilih berdasarkan masa kerja responden, riwayat penyakit hipertensi dan anemia. Sedangkan untuk sampel udara diambil 2 titik pada masing-masing 5 SPBU di ruas jalan perintis kemerdekaan SPBU. Data dikumpulkan melalui kuesioner, pengukuran langsung kepada responden dan pemeriksaan timbal di lingkungan SPBU dengan menggunakan metode AAS. Data dianalisis menggunakan korelasi rank spearman dan regressi linier berganda. Hasil penelitian menunjukkan bahwa tidak ada hubungan antara kadar timbal SPBU dengan kadar timbal dalam darah operator SPBU ( $\mathrm{p}=0.487, \mathrm{r}=0.132)$; ada hubungan antara umur dengan kadar timbal dalam darah operator SPBU ( $\mathrm{p}=0.016, \mathrm{r}=0.436)$; ada hubungan antara masa kerja dengan kadar timbal dalam darah operator SPBU ( $\mathrm{p}=0.001, \mathrm{r}=0.558$ ); ada hubungan antara jumlah rokok yang dikonsumsi dengan kadar timbal dalam darah operator SPBU ( $\mathrm{p}=0.004, \mathrm{r}=0.510)$; ada hubungan antara kadar timbal dalam darah dengan kadar Hb operator SPBU ( $\mathrm{p}=0.003, \mathrm{r}=-0.521$ ); tidak ada hubungan antara kadar timbal dalam darah dengan tekanan darah systole $(\mathrm{p}=0.139, \mathrm{r}=0.277)$ maupun diastole $(\mathrm{p}=0.278, \mathrm{r}=0.205)$. Diharapkan penggunaan APD (Masker) dalam beraktivitas dilingkungan SPBU dan dan melakukan pemantauan kesehatan yang teratur dengan minimal 1 tahun sekali.
\end{abstract}

Kata kunci :Hb, Operator SPBU, Pb Darah, Pb Udara, Tekanan Darah

\begin{abstract}
The research aimed at investigating the relationship between the lead $(P b)$ exposure and lead $(P b)$ concentration in the blood and blood pressure and $\mathrm{Hb}$ of the attendants of the Petrol on Jl. Perintis Kemerdekaan. The research used an observational method with the cross sectional design. This research samples were as many as 30 respondents who were selected by tenure worker, history of hypertension and anemia. For air samples was each on two points of 5 Petrol Stations on Jl. Perintis Kemerdekaan. The research results indicates that there is no relationship between the lead content of the Petrol Stations and lead content in the blood of the attendants of the Petrol Stations $(p=0487, r=0132)$. There is relationship between the age and lead content in the blood of the attendants of the Petrol Stations $(p=0.016, r=0436)$. There is relationship between the working period and lead content in the blood of the attendants of the Petrol Stations $(p=0.001, r$ $=0.558)$. There is relationship between the number of cigarettes consumed and lead content in the blood of the attendants of the Petrol Stations $(p=0.004, r=0.510)$. There is relationship between the lead content and Hb in the blood of the attendants of the Petrol Stations $(p=0.003, r=-0521)$. There is no relationship between the lead content in the blood and the systolic blood pressure $(p=0139, r=0277)$ and diastolic blood pressure $(p=$ $0.278, r=0.205)$.
\end{abstract}

Key-words: Hb, Petrol Station attendants, blood Pb, air Pb, blood Pressure 


\section{PENDAHULUAN}

Timbal atau $\mathrm{Pb}$ merupakan hasil sampingan dari pembakaran mesin-mesin kenderaan bermotor yang berfungsi untuk meningkatkan nilai oktan dan sebagai bahan aditif anti ketuk (anti-knock) pada mesin-mesin kenderaan (Widowaty dkk., 2008). Jumlah senyawa timbal tidak terbakar musnah dalam peristiwa pembakaran pada mesin menyebabkan jumlah timbal yang dibuang ke udara melalui asap buangan kenderaan menjadi sangat tinggi (Palar, 2008). Menurut Environment Project Agency, sekitar 25\% logam berat Timbal $(\mathrm{Pb})$ tetap berada dalam mesin dan $75 \%$ lainnya akan mencemari udara sebagai asap knalpot. Emisi $\mathrm{Pb}$ dari gas buangan tetap akan menimbulkan pencemaran udara dimanapun kendaraan itu berada, tahapannya adalah sebanyak $10 \%$ akan mencemari lokasi dalam radius kurang dari $100 \mathrm{~m}, 5 \%$ akan mencemari lokasi dalam radius $20 \mathrm{~km}$, dan $35 \%$ lainnya terbawa atmosfer dalam jarak yang cukup jauh (Gusnita, 2012). Timbal yang dilepas ke udara sebagai akibat dari pembakaran merupakan ancaman serius bagi kesehatan masyarakat, karena timbal di udara dapat diabsorpsi melalui pernafasan terutama dalam pembuluh darah paru yang kemudian diedarkan ke seluruh jaringan dan organ tubuh (Palar, 2008).

$$
\text { Timbal merupakan logam }
$$

pencemar yang sangat berbahaya karena dapat terakumulasi dalam tubuh dan menyerang organ-organ tubuh penting yaitu darah (hematology), syaraf (neurologi), dan ginjal (renal) (WHO dalam Mulyadi, 2005). Salah satu gangguan pada sistem hematopoetik yang disebabkan oleh timbal adalah gangguan pada saat pembentukan hemoglobin
(Sofro, 2012). Keracunan timbal dapat meningkatkan kadar protoporfirin dalam eritrosit karena penghambatan sejumlah sintesis enzim dalam jalur (pathway) hem oleh timbal. Timbal menghambat kerja porfobilinogen sintese dan inkorporase $\mathrm{Fe} 2+$ ke dalam hem, yang berakibat pada peningkatan kadar asam d-aminolevulinat, korproporifin dalam urin dan protoporfirin dalam eritrosit (Gaw et al., 2002). Hasil penelitian Mulyadi (2005), menunjukkan kadar timbal udara di ruang pengecetan mobil mencapai 0,065372 ppm, sedangkan rata-rata kadar timbal dalam darah pada pekerja yakni 11,20 ppm. Serta ada pengaruh antara kadar timbal udara dengan kadar timbal dalam darah, dan kadar timbal dalam darah dengan hemoglobin, cystatin $\mathrm{C}$, gangguan hematologis dan gangguan ginjal. Kadar Timbal yang relatif rendah (5-35 $\mu \mathrm{g} / \mathrm{dl})$ akan menimbulkan efek terhadap tekanan darah. Timbal yang terlarut dalam darah akan dibawa oleh darah ke seluruh sistem tubuh. Pada peredarannya darah akan terus masuk ke glomelurus yang merupakan bagian dari ginjal. Ikut sertanya timbal yang terlarut dalam darah ke sistem ginjal mengakibatkan terjadinya kerusakan pada saluran ginjal (Palar, 2008). Ginjal merupakan salah satu sistem pengatur pengontrolan tekanan darah melalui aktivitas sistem renin-angiotensin (Palmer \& Williams, 2007). Berdasarkan penelitian yang dilakukan oleh Fenga et al (2006), di Messina, Italy, terhadap pekerja industry baterai, menunjukkan rata-rata kadar timbal dari 27 pekerja yang diperiksa berada di bawah indeks pajanan biologis ACGIH (30 $\mu \mathrm{g} / \mathrm{ml})$. Dan hasilnya menunjukkan bahwa paparan jangka 
panjang timbal yang rendah dapat meningkatkan tekanan darah pada pekerja. Stasiun pengisian bahan bakar umum (SPBU) merupakan tempat yang sangat potensial mencemari lingkungan di sekitarnya terutama pencemaran udara akibat dari pengeluaran gas buang kendaraan bermotor. Operator SPBU merupakan individu yang berpotensi dapat terpapar timbal melalui uap bensin dan emisi dari gas buang kenderaan bermotor. Adanya bahan kimia di lingkungan kerja memberi beban kerja tambahan pada petugas SPBU sehingga dapat menimbulkan masalah kesehatan. Berbagai hasil penelitian menunjukkan bahwa operator SPBU banyak mengalami gangguan tekanan darah dan penurunan $\mathrm{Hb}$ akibat terpajan timbal melalui uap dan percikan bensin serta emisi dari gas kenderaan bermotor.

Di sepanjang ruas jalan Perintis kemerdekaan terdapat 5 SPBU yang beroperasi untuk melayani kendaraan dari arah luar kota maupun ke arah dalam kota makassar. Posisi SPBU yang berada dekat jalan raya memudahkan petugas operator SPBU terpapar dengan polutan timbal dari asap kendaraan yang melaju di jalan raya. Oleh sebab itu perlu di lakukan penelitian untuk mengetahui dampak yang ditimbulkan dari lingkungan kerja terhadap gangguan kesehatannya. sehingga peneliti tertarik untuk mengambil pengaruh pajanan timbal yang ada di udara sekitar SPBU terhadap konsentrasi timbal dalam darah, tekanan darah, dan $\mathrm{Hb}$ pada operator SPBU yang berada di sepanjang Ruas Jalan Perintis Kemerdekaan Kota Makassar.

\section{METODE}

2.1 Lokasi Penelitian

Penelitian ini dilakukan di 5 SPBU yang terletak diruas Jalan Perintis Kemerdekaan, Kota Makassar, Provinsi Sulawesi Selatan masing-masing adalah SPBU 74.902.38 Kilometer 9, SPBU 74.902.22 Kilometer 10, SPBU 74.902.88 Kilometer 11, SPBU 71.902.77 Kilometer 16 dan SPBU 74.902.08 Kilometer 19.

2.2 Desain dan Variabel Penelitian

Jenis penelitian ini adalah penelitian observasional dengan rancangan Cross Sectional Study. Variabel - variabel faktor resiko adalah kadar timbal SPBU, umur, masa kerja,dan jumlah rokok yang dikonsumsi/hari. Variabel antara adalah kadar timbal dalam darah sedangkan variabel tergantung (efek) adalah kadar $\mathrm{Hb}$ dan tekanan darah.

\subsection{Populasi dan Sampel}

Populasi dalam penelitian ini terdiri dari 2 jenis yakni populasi objek dan subjek. Populasi objek adalah udara di SPBU sedangkan populasi subjek adalah seluruh operator yang bekerja di masingmasing SPBU 74.902.38 Kilometer 9, SPBU 74.902.22 Kilometer 10, SPBU 74.902.88 Kilometer 11, SPBU 71.902.77 Kilometer 16 dan SPBU 74.902.08 Kilometer 19 yang berada di ruas jalan perintis kemerdekaan. Sampel objek terdiri dari 2 titik pada masing-masingSPBU. Titik 1 diambil disekitar stasiun pom bensin dan titik 2 diambil pada pintu keluar SPBU. Sampel subjek adalah operator SPBU yang berjumlah 30 orang yang memenuhi kriteria sebagai sampel. Teknik pengambilan sampel menggunakan metode purposive random sampling. 


\subsection{Pengumpulan Data}

Data primer untuk sampel subjek diperoleh dengan cara melakukan wawancara langsung terhadap responden dengan berpedoman pada kuesioner. Sedangkan data primer untuk sampel objek diperoleh dengan melakukan pengukuran dan observasi. Data sekunder diperoleh dari SPBU, penelusuran buku-buku literature, jurnal penelitian, data-data dari Pemerintah serta artikel yang erat kaitannya dengan penelitian ini.

\subsection{Analisis Data}

Analisa dilakukan dengan program SPSS 21 for Windows dan uji statistik dengan menggunakan uji univariat dengan frekuensi, bivariat dengan uji korelasi rank spearman dan multivariate dengan regressi linier berganda.

\section{HASIL DAN PEMBAHASAN}

Tabel 1. Hasil Pengukuran Kadar Timbal

Darah, Kadar Hb dan Tekanan Darah

\begin{tabular}{|c|c|c|c|c|c|c|}
\hline Variabel & $\mathrm{n}$ & Min. & Max. & Mean & Std. Dev & Sign. \\
\hline $\begin{array}{c}\text { Timbal } \\
\text { Darah }\end{array}$ & 30 & 0.0 & 7.0 & 4.2 & 1.7100 & 0.000 \\
\hline Hb Darah & 30 & 10.4 & 14.2 & 12.437 & 1.0947 & 0.238 \\
\hline $\begin{array}{c}\text { TD- } \\
\text { Sistolik }\end{array}$ & 30 & 100 & 170 & 121.00 & 17.879 & 0.001 \\
\hline $\begin{array}{c}\text { TD- } \\
\text { Diastolik }\end{array}$ & 30 & 60 & 100 & 80.87 & 9.779 & 0.007 \\
\hline
\end{tabular}

Tabel 2. Hubungan antara Karakteristik responden dengan Kadar Timbal dalam darah operator SPBU

\begin{tabular}{|c|c|c|c|c|}
\hline Varibel & $\begin{array}{c}\mathrm{p}- \\
\text { value }\end{array}$ & $\mathrm{r}$ & Kesimpulan & $\begin{array}{c}\text { Kekuatan } \\
\text { korelasi }\end{array}$ \\
\hline $\begin{array}{c}\text { Umur*Kadar } \\
\text { Timbal Darah }\end{array}$ & 0.016 & 0.436 & Ada Korelasi & Sedang \\
\hline $\begin{array}{c}\text { Masa } \\
\text { Kerja*Kadar } \\
\text { Timbal Darah }\end{array}$ & 0.001 & 0.558 & Ada Korelasi & Sedang \\
\hline $\begin{array}{c}\text { Jumlah } \\
\text { rokok/hari*Ka } \\
\text { dar Timbal } \\
\text { Darah }\end{array}$ & 0.004 & 0.510 & Ada Korelasi & Sedang \\
\hline
\end{tabular}

Tabel 3. Hubungan antara kadar timbal SPBU dengan Kadar Timbal dalam darah operator SPBU

\begin{tabular}{|c|c|c|c|c|}
\hline Varibel & $\begin{array}{c}\mathrm{p}- \\
\text { value }\end{array}$ & $\mathrm{r}$ & Kesimpulan & $\begin{array}{c}\text { Kekuatan } \\
\text { korelasi }\end{array}$ \\
\hline $\begin{array}{c}\text { Kadar Timbal } \\
\text { Udara*Kadar } \\
\text { Timbal Darah }\end{array}$ & 0.487 & $\begin{array}{c}0.13 \\
2\end{array}$ & $\begin{array}{c}\text { Tidak Ada } \\
\text { Korelasi }\end{array}$ & Lemah \\
\hline
\end{tabular}

Tabel 4. Hubungan antara kadar timbal SPBU dengan Kadar Hb dalam darah operator SPBU

\begin{tabular}{|c|c|c|c|c|}
\hline Varibel & $\begin{array}{c}\mathrm{p}- \\
\text { value }\end{array}$ & $\mathrm{r}$ & Kesimpulan & $\begin{array}{c}\text { Kekuatan } \\
\text { korelasi }\end{array}$ \\
\hline $\begin{array}{c}\text { Kadar } \\
\text { Timbal } \\
\text { Darah*Kadar } \\
\mathrm{Hb}\end{array}$ & 0.003 & - & $\begin{array}{c}\text { Ada } \\
\text { Korelasi }\end{array}$ & Sedang \\
\hline
\end{tabular}

Tabel 5. Hubungan antara kadar timbal SPBU dengan Tekanan darah operator SPBU

\begin{tabular}{|c|c|c|c|c|}
\hline Varibel & $\begin{array}{c}\mathrm{p}- \\
\text { value }\end{array}$ & $\mathrm{r}$ & $\begin{array}{c}\text { Kesimpula } \\
\mathrm{n}\end{array}$ & $\begin{array}{c}\text { Kekuatan } \\
\text { korelasi }\end{array}$ \\
\hline $\begin{array}{c}\text { Kadar Timbal } \\
\text { Darah*TD } \\
\text { Sistole }\end{array}$ & 0.139 & 0.277 & $\begin{array}{c}\text { Tidak Ada } \\
\text { Korelasi }\end{array}$ & Lemah \\
\hline $\begin{array}{c}\text { Kadar Timbal } \\
\text { Darah*TD } \\
\text { Diastole }\end{array}$ & 0.278 & 0.205 & $\begin{array}{c}\text { Tidak Ada } \\
\text { Korelasi }\end{array}$ & Lemah \\
\hline
\end{tabular}

Tabel 6. Hasil analisis regressi linier berganda antara Variabel Potensial dengan Kadar timbal dalam darah

\begin{tabular}{|c|c|c|c|c|}
\hline Variabel & $\mathrm{B}$ & Beta & $\mathrm{t}$ & $\mathrm{p}$-value \\
\hline Masa kerja & 0.125 & 0.320 & 1.983 & 0.058 \\
\hline $\begin{array}{c}\text { Jumlah rokok yang } \\
\text { dikonsumsi/hari }\end{array}$ & 0.088 & 0.414 & 2.566 & 0.016 \\
\hline
\end{tabular}

Berdasarkan uji statistic antara kadar timbal SPBU dan kadar timbal dalam darah diperoleh nilai $\mathrm{p}>0.05$, tidak terdapat hubungan yang signifikan antara kadar timbal SPBU dengan kadar timbal dalam darah.

Kadar timbal di udara yang berasal dari asap kenderaan bermotor maupun 
penguapan bensin dapat masuk ke dalam tubuh operator melalui saluran nafas. Timbal yang terhirup masuk ke paru-paru dan akan berkaitan dengan darah serta diedarkan keseluruh jaringan organ tubuh. Timbal yang diabsorbsi oleh tubuh akan mengikat sel darah merah kemudian didistribusikan ke dalam darah, cairan ekstraseluler, dan beberapa tempat deposit jaringan lunak (hati, ginjal dan saraf) dan jaringan mineral (tulang dan gigi). Oleh karena itu timbal dapat terdeteksi dalam tubuh manusia melalui darah, jaringan lunak dan jaringan mineral (tulang, kuku, rambut dan gigi) (Darmono, 2010).

Berdasarkan uji statistic antara variabel umur dan kadar timbal dalam darah diperoleh nilai $\mathrm{p}=0.016, \mathrm{r}=0.436$, terdapat hubungan yang signifikan antara variabel umur dan kadar timbal dalam darah dimana kadar timbal dalam darah $43.6 \%$ dipengaruhi oleh umur. Umur dapat mempengaruhi kadar timbal dalam tubuh. Semakin tua umur seseorang maka akan semakin tinggi pula kadar timbal yang terakumulasi pada jaringan tubuhnya karena aktivitas enzim biotransformase berkurang seiring dengan peningkatan usia dan daya tahan organ-organ tertentu dalam menurunkan timbal (Palar, 2008). Sejalan dengan hasil penelitian yang dilakukan oleh Ayu, et al. (2014), terhadap operator SPBU di Makassar, berdasarkan analisis korelasi spearman diperoleh nilai $\mathrm{p}=0.000$ dan nilai koefisien korelasi $r=0.606$, sehingga dapat disimpulkan bahwa terdapat hubungan yang bermakna antara umur dengan kadar timbal dalam darah. Nilai koefisien korelasi 0.606 menunjukkan $60.6 \%$ kadar timbal dalam darah dipengaruhi oleh umur.

Hasil uji statistic antara masa kerja dengan kadar timbal dalam darah diperoleh nilai $\mathrm{p}=0.001, \mathrm{r}=0.558$, artinya ada hubungan yang signifikan antara masa kerja dan kadar timbal dalam darah, dimana sebesar $55.8 \%$ masa kerja mempengaruhi kadar timbal dalam darah. Masa kerja yang telah lama dapat meningkatkan akumulasi timbal dalam darah, karena telah lama menghirup udara yang telah terkontaminasi oleh emisi gas buang kenderaan. Timbal memiliki sifat kumulatif dan karsinogenik dalam tubuh manusia, sehingga seseorang dengan masa kerja yang lama memungkinkan orang tersebut mengalami gangguan kesehatan yang disebabkan oleh pencemaran timbal di udara (Patrick, 2006). Hasil penelitian ini sejalan dengan penelitian yang dilakukan oleh Nurbaya \& Wijayanti (2010), terhadap operator SPBU Semarang, menunjukkan bahwa ada hubungan antara masa kerja dengan kadar timbal dalam darah pada petugas operator SPBU 44. 502.02 Semarang dengan pvalue adalah $0,001(<0,05)$.

Hasil uji statistic antara jumlah rokok yang dikonsumsi dengan kadar timbal dalam darah diperoleh nilai $\mathrm{p}=0.004, \mathrm{r}=0.510$, hasil ini menunjukkan ada hubungan yang signifikan antara jumlah rokok yang dikonsumsi dengan kadar timbal dalam darah, dimana kadar timbal dalam darah $51 \%$ dipengaruhi oleh jumlah rokok yang dikonsumsi. Kebiasaan merokok merupakan salah satu hal yang dapat mempercepat absorbs timbal dalam tubuh, hal ini dikarenakan asap yang bersifat iritan dan menyebabkan kakunya cilia atau rambut getar pada saluran pernafasan sehingga tidak berfungsi sebagaimana mestinya. Akibatnya silia tidak dapat menyaring udara yang tercemar timbal ketika masuk ke dalam saluran pernafasan, sehingga timbal mudah 
masuk ke dalam paru-paru (Khan et al., 2014). Selain itu rokok yang bahan bakunya dari tembakau dalam proses penanganannya menggunakan pestisida, juga mengandung bahan dasar timbal (WHO dalam Nurbaya \& Wijayanti, 2010). Hasil penelitian ini sejalan dengan penelitian yang dilakukan oleh Ahmad et al (2014), terhadap pekerja industry baterai di Bangladesh, berdasarkan hasil uji statistic diperoleh nilai $\mathrm{p}=0.012$, artinya terdapat hubungan yang signifikan antara jumlah rokok/hari dengan kadar timbal dalam darah.

Timbal merupakan logam pencemar yang sangat berbahaya karena dapat terakumulasi dalam tubuh dan menyerang organ-organ tubuh penting yaitu darah (hematology), syaraf (neurologi), dan ginjal (renal). Salah satu gangguan pada sistem hematopoetik yang disebabkan oleh timbal adalah gangguan pada saat pembentukan hemoglobin (Sofro, 2012). Berdasarkan uji korelasi antara kadar timbal dalam darah dengan kadar $\mathrm{Hb}$ diperoleh nilai $\mathrm{p}=0.003, \mathrm{r}=-$ 0.521, hasil uji statistic menunjukkan ada hubungan yang bermakna antara kadar timbal dalam darah dengan kadar $\mathrm{Hb}$. Besar hubungan kedua variabel adalah 0.521 artinya kadar hb $52.1 \%$ dipengaruhi oleh kadar timbal dalam darah. Penelitian yang sejakan dilakukan oleh Muliyadi (2015), terhadap pekerja pengecetan mobil di Semarang, diperoleh p-value $=0.008$ dan nilai koefisien korelasi $r=-0.609$. Hasil ini menunjukkan ada hubungan yang signifikan antara kadar timbal didalam darah dengan kadar hemoglobin darah, dengan besar hubungan $60.9 \%$. Kadar timbal dalam darah dapat mengganggu sintesis heme dengan menghambat porfobilinogen sintese dan inkorporasi
$\mathrm{Fe} 2+$ ke dalam hem, yang berakibat pada peningkatan kadar asam d-aminolevulinat, koproporifin dalam urin dan protoporfirin dalam eritrosit (Gaw et al., 2002).

Pada kadar yang relatif rendah (5$35 \mu \mathrm{g} / \mathrm{dl}$ ) timbal dapat menimbulkan efek terhadap tekanan darah. Hasil uji statitik menunjukkan bahwa tidak ada hubungan antara kadar timbal dalam darah dengan tekanan darah baik systole maupun diastole $(p>0.05)$. Timbal yang terlarut dalam darah akan dibawa oleh darah ke seluruh sistem tubuh. Pada peredarannya darah akan terus masuk ke glomelurus yang merupakan bagian dari ginjal. Ikut sertanya timbal yang terlarut dalam darah ke sistem ginjal mengakibatkan terjadinya kerusakan pada saluran ginjal (Palar, 2008). Menurut Palmer \& Wiliams (2007), ginjal merupakan salah satu sistem pengatur pengontrolan tekanan darah melalui aktivitas sistem renin-angiotensin.

\section{KESIMPULAN DAN SARAN}

\subsection{Kesimpulan}

Penelitian ini menyimpulkan tidak ada hubungan yang signifikan antara kadar timbal udara dengan kadar timbal dalam darah operator SPBU, ada hubungan yang signifikan antara umur, masa kerja, jumlah rokok/hari dengan kadar timbal dalam darah operator SPBU, ada hubungan yang signifikan antara kadar timbal dalam darah dengan kadar $\mathrm{Hb}$ operator SPBU, tidak ada hubungan yang signifikan antara kadar timbal dalam darah dengan tekanan darah (sistole dan diastole) operator SPBU.

\subsection{Saran}

Diharapkan penggunaan APD (Masker) untuk mengurangi paparan timbal dari gas buang kendaraan bermotor, dan melakukan pemantauan kesehatan yang teratur dengan minimal 1 tahun sekali. 
Penelitian ini sudah melalui uji etik di Fakultas Kedokteran UNHAS, dengan nomor Register UH16030198.

\section{UCAPAN TERIMA KASIH}

Penelitian ini dapat dilaksanakan dengan baik berkat bantuan dari berbagai pihak. Maka dari itu penulis mengucapkan terima kasih kepada PT. Pertamina (Persero) Makassar, para operator SPBU dan Balai K3 Makassar yang telah bekerja sama dengan baik dalam pelaksaan penelitian ini.

\section{DAFTAR PUSTAKA}

1. Ahmad S. A. et al. (2013). Blood Lead Levels and Health Problems of Lead Acid Battery Workers in Bangladesh. The Scientific World Journal. Volume 2014, 7 page

2. Ayu Friska et al. (2014). Factors Related To the Lead Levels $(\mathrm{Pb})$ On Blood In The Gas Station Operator Tamalanrea Makassar. International Refereed Journal of Engineering and Science (IRJES). ISSN (Online) 2319183X, (Print) 2319-1821 Volume 3, Issue 11 (November 2014), PP.53-58.

3. Darmono. (2010). Lingkungan Hidup dan Pencemaran, Hubungannya dengan Toksikologi Senyawa Logam. Jakarta: UI Press.

4. Fenga C. et al. (2006). Relationship of blood lead levels to blood pressure in exhaust battery storage workers. Ind Health, 44(2), 304-309.

5. Gaw et al. (2012). Biokimia Klinis Edisi 4. Jakarta: Penerbit Buku Kedokteran EGC.

6. Gusnita D. (2012). Pencemaran Logam Berat Timbal $(\mathrm{Pb})$ di Udara dan Upaya Penghapusan Bensin Bertimbal. Berita Dirgantara, 13(3). Diakses 11 Februari 2016. available from http://www.jurnal.lapan.go.id.
7. Khan S. et al. (2014). Smoking-related chronic obstructive pulmonary disease (COPD). Diversity and Equality in Health and Care 2014;11:267-271.

8. Mifbakhuddin M. (2013). Gambaran Status Gizi Dan Profil Darah Petugas Operator Spbu Yang Terpapar Gas Buang $(\mathrm{Pb})$ Kendaraan Bermotor Di Kota Semarang. Jurnal Ekologi Kesehatan, 12(2 Jun), 151-159.

9. Muliyadi M. (2015). Paparan Timbal Udara Terhadap Timbal Darah, Hemoglobin, Cystatin C Serum Pekerja Pengecatan Mobil. Jurnal Kesehatan Masyarakat, 11(1), 87-95.

10. Mulyadi. (2005). Pengaruh Logam Berat Timbal $(\mathrm{Pb})$ Dalam Darah terhadap Kadar Hemoglobin pada juru parkir di Kota Makassar. UNHAS, Makassar

11. Nurbaya F. \& Wjayanti Y. (2010). Faktor risiko yang berhubungan dengan kadar timah hitam dalam darah. Jurnal Kesehatan Masyarakat, 6(1).

12. Palar H. (2008). Pencemaran dan Toksikologi Logam Berat. Jakarta : Rineka Cipta.

13. Palmer \&Williams. (2007). Simple Guide Tekanan Darah Tinggi. Jakarta : Penerbit Erlangga

14. Patrick L. (2006). Lead toxicity, a review of the literature. Part I: exposure, evaluation, and treatment. Alternative Medicine Review, 11(1), 223.

15. Sofro A. S. M. (2012). Darah. Yogyakarta: Pustaka Pelajar

16. Widowaty W. dkk. (2008). Efek Toksik Logam (Pencegahan dan Penanggulangan pencemaran). Bandung: Penerbit Andi 